究机构和学校韭10个单位，在上海召开了时政工作专 門小組会議。

会上，代表們集中討論了当前徐家漼覌象台的时 間工作和今后全国时政工作的發展方針和具体措施， 深入地考观了天文測时、时号播的交鐘、时号收 录等主要工作。最后代表們一教通过了以下三点意見:

1. 为了促进我国时政工作䞟上世界先进水平, 有 必要成立时政委員会及其所風专門小組，扭建議虫中 国科学院数学物理学化学部領导。

2. 徐家淮覌象台目前时号可以适应天文大地測量 工作的当前需要, 希望更进一步努力, 使授时工作枉 上先进国家的水平。

3. 为了提高該台时間工作的質量、推进全国时政 工作以及全国时政工作者的婪密合作，抹研究測时的 地方因素以及柾度的測定等, 应当在国內現有的基础 上增加設备，在科学院紫金山天文台、国家测繪总局、 总参測繪局、科学院測量制圖研究室和武汉测量制圖

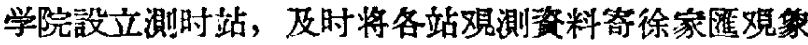
台統一处理应用。

代表們就有关的原則性和学术性問題广泛地交换 了意見，肝展开了热烈的討論，肝商討了今后具体合 作的方案。

\section{〔王 揚〕}

\section{中国科学院遗傳学研究工作 委员会成立会議}

中国科学院遗傅学研究工作委員会于1957年12月 10-12 日在北京召开成立会議。这是 糍 1956 年 8 月在青岛举行的遺傳学座談会之后又一項推动遗傳学 的重要措施。

会議根据国家十二年科学远景規划及我国国民經 济建設和国防的要求挂参照国际遺傅学的發展方向及 苏联科学家对我国科学远景規划第 56 項任务和 学科 規划中有关虺傳学部分所提的意見，經过两天的反复 时諭，提出“关于遗傅学的今后弦展方向及目前重 点 研究項目的建議”。

“建議”中提出四項遗傳学的今后發垡方向: (一) 遗傅物票的本質。从核肌和核酸的构造和作用; 遗傅 物質与代謝的关系，特別是与生物合成的关系; 环境 对核脂生物合成的影响等方面进行探䇣。（二)变异及 其机制。研究各种环境条件的弯变作用; 輻射的誘变 作用及其与其它因素的关系; 各种变异的遺傅規律; 异筫性原理（包括异質性形成的条件; 有性和無性的 杂种优势）等問題。（三)遗傳性个体弡有的关系。进 行遺傅与細胞分分化的关系; 遭傅性表現的过程与条
件（包括植物的阶段發有）; 遺傅性的控制与定向培育 等研究。(四)遺傅与系統的关系。包括研究种內 遗傳差异与种間遺傳墓异的关系; 䢙傅与 适应的关 系; 多倍体形成問題等內容。关于目前重 点研 究 項 目, “建議”中提出杂种优势的理諭、利用及保持; 䄧 發变异的利用，特別是棕合新变的利用，如多倍体与 輻射誘变的配合应用; 輻射对生物頲傳的影响及其防 止的方法; 微生物遺傳 (包括病毒); 精济动植物的遺 傳型与生态型的相互关系及其新类型形成的理論研究 等五項。会議初步安排了这些重点研究項目的主要俱 責单位, 种对有关遗傅研究单位的 1958 年研究計划 提出一些意見。

遺傅学今后發留方向和目前重点研究項目的建㖣 体現了委員們的集体智慧，它对于各有关方面修訂的 和制訂的遺傳学远景規划和研究計划将有很大的淩考 价值。但由于会期較短，目前只能提代綱姴性的初步 建議，需要逐步修訂㪶加以具体化。

关于数学和培养于部問題，会議对一些高等院校 遭傳学专業和专門化的設道、培养目标、課程安排、 招生人数和吸收进修生等提供了具体建訸，弗希望高 等教育部和中国科学院利用假期举办遗傳学講座。編 譯出版方面，会議就翻譯和影印国外遀傳学期刊、普 籍以及稨纂遺傅学辞典、名詞等問題进行了具体討

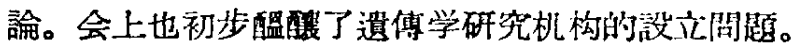
会議还討論通过了遗傅学研究工作委員会簡則。 簡則規定委員会的任务是䂠制倍頲傳学研究工作的方 針任务，协調研究計划，組糡人力物力，协助处理国 內外的学术联系和翻譯国內外重要期利与著作，以及 培养人材等方面向各有关部門提供建議。委貝会还㭥 责召开遺侮学研究工作的学术会議。

委員会由中国科学院、高等院校和产業部門研究

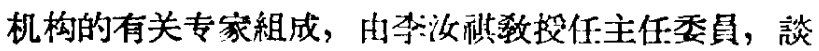
家槙敉授、祖德明敨授任副主任委貴。

〔宋振能〕

\section{本政道、楊振宁 接受諾貝尔奖金}

中国物理学家李政道、楊振宁于1957年12月10日 在斯德哥尔摩接受了1957年物理学奖金。

1957年諾只尔化学奖金获得者是英国皇家学会会 員、劍桥大学有机化学教投 $\mathrm{A}$ - 托德。托德以其关于 核酸的研究聞名于世:。

意大利的D - 波維特博士，以其关于合成箱青的. 生产方面的研究获得1957年諾員尔生理学医学奖金. 